\title{
Prevalence and characteristics of children with chronic respiratory symptoms in eastern Finland
}

\author{
K.L. Timonen*, J. Pekkanen*, M. Korppi**, M. Vahteristo*, R.O. Salonen+
}

Prevalence and characteristics of children with chronic respiratory symptoms in eastern Finland. K.L.Timonen, J. Pekkanen, M. Korppi, M. Vahteristo, R.O. Salonen, @ERS Journals Ltd 1995.

ABSTRACT: The objective of the present study was to assess the prevalence of asthma and asthma-related symptoms in Finland. We also wondered whether chronic cough may be an indicator of occult asthma.

Prevalence and characteristics of children with doctor-diagnosed asthma and chronic respiratory symptoms were investigated in 7-12 year old school children from eastern Finland by using a questionnaire on respiratory symptoms. In addition, skin-prick tests, flow-volume spirometry, and serum total immunoglobulin $\mathrm{E}$ (IgE) measurements were performed in children reporting chronic respiratory symptoms.

The parent-reported prevalence of doctor-diagnosed asthma was $4.4 \%$, of wheezing $5.4 \%$, of attacks of shortness of breath with wheezing $4.6 \%$, and of dry cough at night $12 \%$. Children with dry cough only $(n=195)$ had less frequent parental asthma, self-reported allergies, daily respiratory medication, and moisture stains or molds at home than asthmatic children $(n=180)$, but these findings were more frequent than among asymptomatic children $(n=2,169)$. The prevalence of at least one positive skin-prick test result was $79 \%$ among the asthmatic children and $55 \%$ among children with dry cough only. There were no differences between the two symptom groups in serum total IgE levels and spirometric lung functions, except in maximal mid-expiratory flow (MMEF) values, which were significantly lower among children with asthmatic symptoms.

The present results support the hypothesis that chronic cough may be an indicator of occult asthma. Therefore, to improve the sensitivity of respiratory questionnaires designed to detect asthma, they should also include questions on chronic cough. In contrast to what has been suggested previously, the prevalence of childhood asthma in eastern Finland was similar to the prevalences reported from other parts of Finland and from other Western European countries.

Eur Respir J., 1995, 8, 1155-1160.
*Dept of Environmental Epidemiology and +Dept of Toxicology, Division of Environmental Health, National Public Health Institute, Kuopio, Finland. **Dept of Pediatrics, Kuopio University Hospital, Finland.

Correspondence: K. Timonen, National Public Health Institute, Dept of Environmental Epidemiology, P.O.Box 95, FIN70701 Kuopio, Finland.

Keywords: Children, prevalence, respiratory symptoms, skin-prick tests, spirometry.

Received: August 231994

Accepted after revision April 101995

The data were collected within the framework of the "Pollution Effects on Asthmatic Children in Europe" (PEACE) study. The PEACE study is a study on effects of short-term variations in urban air pollution on the respiratory health of children with chronic respiratory symptoms. The study was funded by the EU Environment Programme Contract EV5V-CT920220 (seven centres) and two additional EU PECO contracts to allow participation of five centres in Central and Eastern Europe. The Finnish, Norwegian and two Swedish centres were funded by grants from the respective governments. The study was co-ordinated by the Department of Epidemiology and Public Health, University of Wageningen, The Netherlands.
Recent studies from many countries [1-4] have suggested an increase in the prevalence of asthma among children and adolescents. In Finland, the prevalence of asthma in children has been reported to be lower than in many other European countries [5]. In addition, the prevalence of doctor-diagnosed asthma has been reported to vary among children living in different parts of Finland. The prevalence was lowest $(0.6 \%)$ in the eastern parts and highest $(3.3 \%)$ in the northern parts of the country [5]. This regional difference has no satisfactory explanation. It may be, at least in part, due to differences in diagnostic practices.

The aim of the present study was to investigate the prevalence of doctor-diagnosed asthma, and of asthmatic and other chronic respiratory symptoms among 7-12 year old children living in eastern Finland. In addition, skin-prick tests, pulmonary function measurements and serum total immunoglobulin E (IgE) measurements were performed among children with chronic respiratory symptoms.

\section{Subjects and methods}

\section{Study design}

The present study was carried out in Kuopio, a town of 80,000 inhabitants in eastern Finland. Children in all of the five primary schools in the centre of the town and in all of the three primary schools in two adjacent suburbs, Jynkkä and Petonen, were invited to enter the study. The study was conducted as a screening phase of a European collaborative project "Pollution Effects on Asthmatic Children in Europe" (PEACE). Fourteen 
study centres in 10 countries are participating in this European collaboration [6]. Results of the collaborative study will be published elsewhere.

In September 1993, a short screening questionnaire was distributed to all of the 2,995 pupils of the selected schools, to be completed by the parents. Altogether, 2,564 $(86 \%)$ of the questionnaires were returned. Of the children who returned the questionnaire, 2,544 were aged 7-12 yrs. In two questionnaires, the sex of the child was missing. A total of 229 children reporting chronic respiratory symptoms were asked to participate in the main study on air pollution [6]. They were from four schools in the centre of town and from two schools in the suburb of Petonen. One hundred and ninety seven of these children (86\%) agreed to participate, and they were also characterized by measuring lung function with a flow-volume spirometer and atopic sensitization with skin-prick tests in November and December 1993. After the main study in summer 1994, the serum total IgE levels were measured in 163 of these children (83\%).

\section{Questionnaire and clinical tests}

The screening questionnaire was an adapted version from two questionnaires used previously: a World Health Organization (WHO) questionnaire for assessing respiratory symptoms in children [7] and a questionnaire developed in the University of Groningen, The Netherlands. The latter is based on the American Thoracic Society questionnaire for children $[6,8]$. In addition, there were questions on pets, wall-to-wall carpeting, moisture stains or molds, smoking habits, and use of wood-burning stove or fireplace at home, both currently and during the first 2 years of the child's life.

Skin-prick tests were performed using the ALK skinprick test allergen panel (ALK Laboratories, Denmark). The allergens tested were birch, common alder, timothy grass and mugwort pollens, and cat and dog epithelial danders, and house dust mite (Dermatophagoides pteronyssinus). Histamine hydrochloride $\left(10 \mathrm{mg} \cdot \mathrm{mL}^{-1}\right)$ and glycerol $(50 \%)$ were used as positive and negative controls, respectively. A history was taken to ensure that no child had taken any antihistaminic drugs within $48 \mathrm{~h}$ before testing [6]. The reactions were read $15 \mathrm{~min}$ after the allergen application by outlining the circumferences of all resulting weals on the skin, and by transposing them to a data collection sheet with transparent tape. A mean weal diameter of $2 \mathrm{~mm}$ or more was regarded as a positive result [6]. The average for the mean weal diameters of the positive controls was $5.3 \mathrm{~mm}$. One child reacted to the negative control, and his results were excluded from analyses. Additional analyses were carried out also using a mean weal diameter of $3 \mathrm{~mm}$ or more as the cut-off point.

The serum total IgE levels were determined by using Pharmacia IgE radio-immunoassay test (RIA) (KabiPharmacia Diagnostics AB, Uppsala, Sweden). IgE levels over $320 \mathrm{kU} \cdot \mathrm{L}^{-1}$ were regarded as abnormally elevated values in this age group.

Spirometric flow-volume curves were recorded by using a portable computerized spirometer with a heated pneumotachograph (Medikro 909, Medikro Oy, Kuopio, Finland). The measurements were made according to the recommendations of the European Respiratory Society [6, 9]. All pulmonary function tests were performed at schools between 10.00 a.m. and 3 p.m. Every morning before the measurements, the spirometer was calibrated for volume with a $3 \mathrm{~L}$ syringe. The subjects were seated and used a noseclip. All but one child had not used beta $2^{-}$ sympathomimetic, anticholinergic or corticosteroid inhalers for at least $6 \mathrm{~h}$ before the measurements, and any other inhaler $1 \mathrm{~h}$ and oral beta ${ }_{2}$-sympathomimetic or theophylline $8 \mathrm{~h}$ before the measurements [6]. The largest values of forced vital capacity (FVC), forced expiratory volume in one second (FEV1), and peak expiratory flow (PEF) were selected from a minimum of three valid expiratory recordings. The largest maximal mid-expiratory flow (MMEF) was selected from a recording with the FVC value within $5 \%$ of the largest FVC $[6,9]$. All spirometric results are corrected to body temperature, atmospheric pressure and saturation with water vapour (BTPS). Predicted values for Finnish children, based on sex and height of the subjects, were obtained from SALORINNE [10].

The study protocol was approved by the Ethics Committee of the University of Kuopio and of the Kuopio University Hospital.

\section{Definitions and statistical analyses}

Children with doctor-diagnosed asthma, and those who had suffered from wheezing or attacks of shortness of breath with wheezing during the previous 12 months, were defined as having "asthmatic symptoms". Children, who did not have "asthmatic symptoms", but had suffered from dry cough at night not associated with colds, were defined as having "dry cough only". Any "asthmatic symptom" and dry cough at night during the previous 12 months constituted "chronic respiratory symptoms". All other children were classified as having "no respiratory symptoms".

Data were analysed using the statistical package SAS/ STAT® (SAS Institute Inc., Cary, NC, USA). The CochranMantel-Haenszel test was used to examine the significance of differences between proportions, and the analysis of variance was used to test the significance of differences between the means. As there were no differences between the centre and suburbs of Kuopio in the prevalences of different respiratory symptoms, the results of the two areas are presented as combined.

\section{Results}

Boys had significantly $(\mathrm{p}<0.05)$ more doctor-diagnosed asthma, and during the last 12 months they more frequently had wheezing, any asthmatic symptom, dry cough at night and any chronic respiratory symptom than girls (table 1). There was no significant trend with age in the prevalences of any of the respiratory symptoms among either sex. 
Table 1. - The prevalence of doctor-diagnosed asthma and of chronic respiratory symptoms among children aged 7-12 yrs in eastern Finland

\begin{tabular}{lcccc}
\hline & $\begin{array}{c}\text { Boys } \\
(\mathrm{n}=1,241) \\
\%\end{array}$ & $\begin{array}{c}\text { Girls } \\
(\mathrm{n}=1,301) \\
\%\end{array}$ & $\begin{array}{c}\text { All } \\
(\mathrm{n}=2,542)\end{array}$ & $\mathrm{p}$-value* \\
& 5.6 & 3.2 & 4.4 & $<0.01$ \\
\hline $\begin{array}{l}\text { Doctor-diagnosed } \\
\text { asthma }\end{array}$ & 6.3 & 4.5 & 5.4 & $<0.05$ \\
$\begin{array}{l}\text { Wheezing during } \\
\text { the last } 12 \text { months }\end{array}$ & & & & \\
$\begin{array}{l}\text { Shortness of breath } \\
\text { with wheezing, } \\
\text { during the last } 12\end{array}$ & 5.2 & 4.2 & 4.7 & $\mathrm{NS}$ \\
months & & & & \\
$\begin{array}{l}\text { Any of the three } \\
\text { findings above }\end{array}$ & 8.5 & 5.7 & 7.1 & $<0.01$ \\
$\begin{array}{l}\text { Dry cough at night, } \\
\text { during the last } 12 \\
\text { months }\end{array}$ & 14 & 11 & 12 & $<0.05$ \\
$\begin{array}{l}\text { Any of the four } \\
\text { findings above }\end{array}$ & 17 & 13 & 15 & $<0.05$ \\
\hline
\end{tabular}

*: difference between sexes.

There was a clear overlap in reporting of different asthmatic symptoms. Seventy percent of the children with doctor-diagnosed asthma had suffered from wheezing, $70 \%$ from dry cough at night, and $67 \%$ from attacks of shortness of breath with wheezing during the last 12 months. Similarly, $76 \%$ of the children who had wheezed during the last twelve months had also suffered from attacks of shortness of breath with wheezing, 73\% had had dry cough at night and $57 \%$ reported doctor-diagnosed asthma. Twenty five percent of the children having dry cough at night reported doctor-diagnosed asthma, 32\% had wheezed, and $27 \%$ had suffered from attacks of shortness of breath.

Fifty two percent of the children with chronic respiratory symptoms had dry cough as their only symptom. The prevalences of parental asthma, reported allergies, and daily respiratory medication were lowest among asymptomatic children and highest among children with asthmatic symptoms. This was also true for moisture stains or molds at home during the past 2 yrs, but not for passive smoking, use of a wood-burning stove, or having a wall-to-wall carpet. The children with chronic respiratory symptoms currently had less pets with fur or feathers than the children with no respiratory symptoms (table 2 ).

During the first 2 yrs of life, the children with asthmatic symptoms had also had moisture stains or molds at home $(3.4 \%)$ significantly $(\mathrm{p}<0.05)$ more often than the children with dry cough only $(2.1 \%)$, or the asymptomatic children $(1.5 \%)$. There were no significant differences between these groups of children in exposure to passive smoking, having a wall-to-wall carpet, use of wood-burning stove or fireplace, having pets, or attending a day-care centre during the first 2 years of life (data not shown).

The children with asthmatic symptoms had positive skin-prick test results significantly $(\mathrm{p}<0.01)$ more often than the children with dry cough alone. Among all children, boys had positive skin-prick reactions to birch, mugwort and any pollen significantly $(\mathrm{p}<0.05)$ more often than girls (table 3 ).

Fifteen children with asthmatic symptoms (20\%) and 16 children with dry cough alone (19\%) had a serum total IgE level higher than $320 \mathrm{kU} \cdot \mathrm{L}^{-1}$. This difference was not statistically significant. There was also no significant

Table 2. - Characteristics of children with no respiratory symptoms, with dry cough only, and with asthmatic symptoms

\begin{tabular}{|c|c|c|c|c|}
\hline & $\begin{array}{c}\text { No symptoms } \\
\qquad \begin{array}{c}(\mathrm{n}=2,169) \\
\%\end{array}\end{array}$ & $\begin{array}{l}\text { Dry cough only } \\
\qquad \begin{array}{c}(\mathrm{n}=195) \\
\%\end{array}\end{array}$ & $\begin{array}{c}\text { Asthmatic } \\
\text { symptoms } \\
(\mathrm{n}=180) \\
\%\end{array}$ & p-value ${ }^{\dagger}$ \\
\hline Boys & 48 & 51 & 59 & \\
\hline Parental asthma & 6.7 & 14 & 21 & $<0.001$ \\
\hline $\begin{array}{l}\text { Parent-reported allergies to: } \\
\text { Pollen } \\
\text { Pets } \\
\text { House dust } \\
\text { Other }\end{array}$ & $\begin{array}{l}13 \\
7.2 \\
2.1 \\
13\end{array}$ & $\begin{array}{l}43 \\
29 \\
13 \\
30\end{array}$ & $\begin{array}{l}75 \\
69 \\
43 \\
53\end{array}$ & $\begin{array}{l}<0.001 \\
<0.001 \\
<0.001 \\
<0.001\end{array}$ \\
\hline Daily respiratory medication & 0.5 & 3.1 & 40 & $<0.001$ \\
\hline Chest illness in infancy* & 6.6 & 20 & 27 & $<0.001$ \\
\hline Pet with fur or feathers & 42 & 31 & 18 & $<0.001$ \\
\hline Moisture stain or molds & 4.0 & 8.2 & 9.6 & $<0.001$ \\
\hline Smoking inside at home & 9.4 & 11 & 5.6 & NS \\
\hline Wood-burning stove or fireplace & 36 & 34 & 33 & NS \\
\hline Wall-to-wall carpet & 2.7 & 1.6 & 2.2 & NS \\
\hline
\end{tabular}

*: serious chest illness during the first 2 years of the child's life; $\dagger$ : test of heterogeneity, adjusted for sex and age. 
Table 3. - The prevalence of positive skin-prick reactions and the results of pulmonary function tests among children with either dry cough only or asthmatic symptoms, and among all children with chronic respiratory symptoms

\begin{tabular}{|c|c|c|c|c|c|}
\hline & \multirow{2}{*}{ 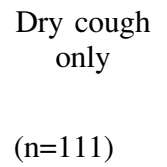 } & \multirow{2}{*}{$\begin{array}{l}\text { Asthmatic } \\
\text { symptoms } \\
(n=86)\end{array}$} & \multicolumn{3}{|c|}{ All } \\
\hline & & & $\begin{array}{c}\text { Boys } \\
(\mathrm{n}=112)\end{array}$ & $\begin{array}{l}\text { Girls } \\
(\mathrm{n}=85)\end{array}$ & $\begin{array}{c}\text { Total } \\
(\mathrm{n}=197)\end{array}$ \\
\hline \multicolumn{6}{|l|}{ Allergen* \% } \\
\hline Birch & 19 & 33 & 31 & $16^{\ddagger}$ & 25 \\
\hline Common alder & 32 & 48 & 45 & 32 & 39 \\
\hline Timothy grass & 34 & $51^{\dagger}$ & 47 & 34 & 42 \\
\hline Mugwort & 11 & 22 & 22 & $7 \ddagger$ & 16 \\
\hline Any pollen & 48 & $70^{\dagger}$ & 64 & $48 \ddagger$ & 57 \\
\hline Cat & 32 & $55^{\dagger}$ & 45 & 39 & 42 \\
\hline Dog & 36 & $52^{\dagger}$ & 46 & 39 & 43 \\
\hline Any pet & 41 & $66^{\dagger}$ & 54 & 48 & 52 \\
\hline House dust mite & 4.5 & $15^{\dagger}$ & 11 & 7 & 9 \\
\hline Any positive prick & 55 & $79^{\dagger}$ & 69 & 61 & 65 \\
\hline \multicolumn{6}{|c|}{ Pulmonary function } \\
\hline FVC $\%$ pred & 99 (12) & 100 & 103 & $94(12)^{+}$ & $99(13)$ \\
\hline FEV1 $\%$ pred & $95(11)$ & 93 (12) & $95(11)$ & $93 \quad(12)$ & $94(11)$ \\
\hline PEF $\%$ pred & $90(17)$ & 86 (16) & $84(15)$ & $93(18)^{+}$ & $88(17)$ \\
\hline MMEF \% pred & 90 (19) & $81 \quad(21)^{\S}$ & $82(19)$ & $92(21)^{+}$ & $86(20)$ \\
\hline
\end{tabular}

Pulmonary function data are presented as mean and SD in parenthesis.*: all allergen concentrations were 10,000 $\mathrm{BU} \cdot \mathrm{mL}^{-1} ;{ }^{\dagger}: \mathrm{p}<0.05$ for difference between the symptom groups, adjusted for sex and age; $*: \mathrm{p}<0.05$ for difference between sexes; $\$: \mathrm{p}<0.01$ for difference between the symptom groups, adjusted for sex and age; ${ }^{+}: \mathrm{p}<0.01$ for difference between sexes. FVC: forced vital capacity; FEV1: forced expiratory volume in one second; PEF: peak expiratory flow; MMEF maximal mid-expiratory flow.

difference with regard to sex or presence of a positive skinprick reaction.

Among the children with asthmatic symptoms, the mean (SD) values of the spirometric lung function parameters were: FVC $2.40(0.55) \mathrm{L}, \mathrm{FEV} 12.01(0.44) \mathrm{L}$, PEF $4.13(1.10) \mathrm{L} \cdot \mathrm{s}^{-1}$ and MMEF $2.24(0.65) \mathrm{L} \cdot \mathrm{s}^{-1}$. The respective values among the children with dry cough only were $2.33(0.61) \mathrm{L}, 2.02(0.49) \mathrm{L}, 4.15(1.05) \mathrm{L} \cdot \mathrm{s}^{-1}$ and $2.44(0.70) \mathrm{L} \cdot \mathrm{s}^{-1}$. As percentage predicted, the MMEF values of the children with asthmatic symptoms were significantly $(\mathrm{p}<0.05)$ smaller than those of the children with dry cough only. Boys had significantly $(\mathrm{p}<0.001)$ larger FVC values than girls, but girls had significantly $(\mathrm{p}<0.01)$ larger PEF and MMEF values than boys (table 3 ).

\section{Discussion}

In the present study, we have found that the lifetime prevalence of doctor-diagnosed asthma was $4.4 \%$, which is clearly higher than the prevalence reported in the $1980 \mathrm{~s}$ among 3-8 year old children in the same area $(0.6 \%)$, and in northern $(3.3 \%)$ and southern Finland (2.1\%) [5]. In the study of PöYsä et al. [5] (1991), the prevalence included children who had both doctor-diagnosed asthma and clinical symptoms during the previous year. In southeastern Finland, a prevalence of $4.2 \%$ was reported among 708 adolescents aged $15-17$ yrs in the late 1970s [11]. The prevalence of doctor-diagnosed asthma was $1.0 \%$ in
1979 and $2.8 \%$ in 1991 among a representative sample of Finnish children aged 12-18 yrs [12]. These differences in prevalences may be due to different formulations of the questions on asthma, but they may also, at least partly, be caused by a true increase in the prevalence of doctordiagnosed asthma [1-4, 13, 14].

Our results on the prevalences of doctor-diagnosed asthma and recent shortness of breath with wheezing agree with a recent Dutch study among children aged 6-12 yrs. In the study by BRUNEKREEF et al. [8] (1992), the same questions were used, and the prevalence of doctor-diagnosed asthma was $4.0 \%$ and of shortness of breath with wheezing $5.9 \%$, compared to $4.4 \%$ and $4.6 \%$ in the present study. Higher prevalences of doctordiagnosed asthma have been reported among school children and adolescents in many other countries: $6.8 \%$ in Sweden [15], 7.2-9.3\% in Germany [16, 17], 12\% in England [18], $10.2 \%$ in Scotland [2], 8.0-16.8\% in New Zealand [19, 20], and $8.3 \%$ in Australia [21]. A recent review reported that the prevalence of childhood asthma varies between 3.1 and $18 \%$ in different parts of Europe [22]. However, a comparison of prevalences reported in different studies is difficult, because there is no "gold standard" for defining asthma in epidemiological studies [23].

In the present study, $5.4 \%$ of the children had suffered from wheezing during the last 12 months. This result is similar to a previously reported study from Switzerland, in which the prevalences of wheezing were 7.4 and $6.0 \%$ 
among children aged 7 and 12 yrs, respectively [24]. Higher prevalences of wheezing have been reported among children in other countries: $10 \%$ in The Netherlands [8], $15 \%$ in England [18], $18 \%$ in New Zealand [20], 21-23\% in Australia and 21-27\% in Chile [24]. Among 12-13 year old children, the self-reported prevalence of wheezing during the previous year has varied between $19 \%$ in Germany, 26\% in New Zealand and 28-30\% in Australia [25]. Thus, the prevalences of both doctor-diagnosed asthma and asthmatic symptoms in eastern Finland seem to be similar to, or somewhat lower than, the corresponding prevalences in several Western European countries, but they are clearly lower than the prevalences in New Zealand and possibly in Australia.

The children with chronic respiratory symptoms more often had moisture stains or molds at home than the asymptomatic children. It is possible that the parents of symptomatic children notice and report moisture problems and molds more readily. However, several previous studies have also suggested that exposure to molds is associated with chronic respiratory symptoms [2630]. Current pet owners had less respiratory symptoms, which indicates pet avoidance in families with children having chronic respiratory symptoms. A similar result has also been reported previously [31].

In the interpretation of skin-prick tests, a mean weal diameter of $2 \mathrm{~mm}$ or more was considered a positive result. The prevalences of positive reactions to timothy grass $(42 \%)$ and common alder pollens $(39 \%)$ were more common than the reactions to birch pollen $(25 \%)$. This finding did not change, when the definition of a positive skin test reaction was changed to a mean weal diameter of $3 \mathrm{~mm}$, the cut-off point used in many studies [32-35]. Such frequent allergy to common alder has not previously been reported in Finland [33, 36]. With the cutoff point of $3 \mathrm{~mm}$, the prevalence of positive reactions to all allergens decreased by a mean of $6.6 \%$ (range from $2.0 \%$ for house dust mite to $14 \%$ for birch pollen).

Most asthmatic children $(77 \%)$ and more than half (54\%) of the children with dry cough only had at least one positive skin test reaction. Similar results have been reported in recent Finnish [34] and Swedish [15] studies, in which the prevalences of at least one positive skin test reaction varied between 66 and $69 \%$ among asthmatic children. In addition, in a study from England, $63 \%$ of wheezy children had at least one positive skin test reaction compared to $37 \%$ among children with dry cough [37]. In unselected populations, the prevalence is lower and usually varies between 17 and 39\% [11, 15, 32, 34-36].

The results of the pulmonary function tests in children with asthmatic symptoms and with dry cough only differed from each other in MMEF values. This may reflect good clinical responses achieved by anti-asthma drugs and by allergen avoidance among the asthmatic children. It has been reported that MMEF is a sensitive index of airway obstruction [38], and, in fact, the smaller MMEF values in the asthmatic children seem to have been the only indicator of airflow obstruction in comparison with the children with dry cough only. Boys had lower PEF and MMEF values than girls, which could, at least in part, be due to the larger proportion of asthmatics among boys $(59 \%)$ than girls $(41 \%)$. Boys had more chronic respiratory symptoms and positive skin-prick reactions than girls, which has also been observed in many previous studies $[2,11,24,39]$. This difference seems to disappear with age and in adolescence girls may even have more respiratory symptoms than boys [15, 24, 40].

Chronic cough is often considered an occult form of asthma [37, 41]. In the present study, the children with dry cough as their only chronic respiratory symptom formed an intermediate group that differed clearly both from the children with asthmatic symptoms and the children with no respiratory symptoms. In a study from England, children with wheeze had bronchial hyperresponsiveness to methacholine more often than children with cough. However, children who had both cough and atopy had higher prevalence of bronchial hyperresponsiveness than nonatopic wheezy children [37]. Children with cough have been reported to have more frequent but less severe episodes of airflow obstruction than wheezy children [42].

The repeatability of questions on asthmatic symptoms has been reported to be good [8]. In the present study, there was also a strong correlation between reporting of different asthmatic symptoms, which made the asthmatic group very homogenous. In contrast to this, the repeatability of questions on cough has been reported to be less satisfactory [8].

The present results support the hypothesis that chronic cough may be an indicator of occult asthma. Therefore, to improve the sensitivity of respiratory questionnaires designed to detect asthma, they should also include questions on chronic cough. In contrast to what has been suggested previously, the prevalence of childhood asthma in eastern Finland was similar to the prevalences reported from other parts of Finland and from other Western European countries.

\section{References}

1. Burney PGJ, Chinn S, Rona RJ. Has the prevalence of asthma increased in children? Evidence from the national study of health and growth 1973-1986. $\mathrm{Br}$ Med J 1990; 300: 1306-1310.

2. Ninan TK, Russel G. Respiratory symptoms and atopy in Aberdeen schoolchildren: evidence from two surveys 25 years apart. $B r$ Med $J$ 1992; 304: 873-875.

3. Anderson HR, Butland BK, Strachan DP. Trends in prevalence and severity of childhood asthma. $\mathrm{Br}$ Med $\mathrm{J}$ 1994; 308: 1600-1604.

4. Haahtela T, Lindholm H, Björkstén F, Koskenvuo K, Laitinen LA. Prevalence of asthma in Finnish young men. Br Med J 1990; 301: 266-268.

5. Pöysä L, Korppi M, Pietikäinen M, Juntunen-Backman K. Asthma, allergic rhinitis and atopic eczema in Finnish children and adolescents. Allergy 1991; 46: 161-165.

6. Brunekreef B, ed. Effects of short-term changes in urban air pollution on the respiratory health of children with chronic respiratory symptoms: study procedures for collaborative study funded by the Commission of the European Communities in the framework of the 
"Environment" RDT Programme. Wageningen Agricultural University, 1993.

7. Florey $\mathrm{C} \mathrm{du} \mathrm{V,} \mathrm{Leeder} \mathrm{SR.} \mathrm{Methods} \mathrm{for} \mathrm{cohort} \mathrm{studies}$ of chronic airflow limitation. WHO regional publications, European series No. 12, Copenhagen, 1982.

8. Brunekreef B, Groot B, Rijcken B, et al. Reproducibility of childhood respiratory symptoms questions. Eur Respir J 1992; 5: 930-935.

9. Quanjer PH, Tammeling GJ, Cotes JE, et al. Standardized lung function testing. Eur Respir J 1993; 6 (Suppl. 16): 5-40.

10. Salorinne Y. Reference values for flow-volume spirometry in children. VIIIth Scandinavian Congress of Clinical Physiology, Helsinki, 1989; Abstract 30.

11. Haahtela T, Heiskala M, Suoniemi I. Allergic disorders and immediate skin test reactivity in Finnish adolescents. Allergy 1980; 35: 433-441.

12. Rimpelä A, Savonius B, Rimpelä M, Haahtela T. Asthma and allergic rhinitis among Finnish adolescents in 19771991. Scand J Soc Med 1995; 23: 60-65.

13. Phelan PD. Asthma in children: epidemiology. Changing prevalence, patterns, and treatment. Br Med J 1994; 308: 1584-1585.

14. Peat JK, van den Berg RH, Green WF, et al. Changing prevalence of asthma in Australian children. $\mathrm{Br}$ Med $\mathrm{J}$ 1994; 308: 1591-1596.

15. Norrman E. Rosenhall L, Nyström L, Bergström E, Stjernberg N. High prevalence of asthma and related symptoms in teenagers in Northern Sweden. Eur Respir J 1993; 6: 834-839.

16. von Mutius E, Fritzsch C, Weiland SK, Röll G, Magnussen $\mathrm{H}$. Prevalence of asthma and allergic disorders among children in united Germany: a descriptive comparison. Br Med J 1992; 305: 1395-1399.

17. von Mutius E, Martinez FD, Fritzsch C, et al. Prevalence of asthma and atopy in two areas of West and East Germany. Am J Respir Crit Care Med 1994; 149: 358 364.

18. Burr ML, Butland BK, King S, Vaughan-Williams E. Changes in asthma prevalence: two surveys 15 years apart. Arch Dis Child 1989; 64: 1452-1456.

19. Shaw RA, Crane J, O'Donnell TV, Porteous LE, Coleman ED. Increasing asthma prevalence in a rural New Zealand adolescent population: 1975-1989. Arch Dis Child 1990; 65: 1319-1323.

20. Barry DMJ, Burr ML, Limb ES. Prevalence of asthma among 12 year old children in New Zealand and South Wales: a comparative survey. Thorax 1991; 46: 405-409.

21. Bauman A. Has the prevalence of asthma symptoms increased in Australian children? J Paediatr Child Health 1993; 29: 424-428.

22. Carlsen K-H. Epidemiology of childhood asthma. Eur Respir Rev 1994; 4: 5-9.

23. Toelle BG, Peat JK, Salome CM, Mellis CM, Woolcock AJ. Toward a definition of asthma for epidemiology. Am Rev Respir Dis 1992; 146: 633-637.

24. Robertson CF, Bishop J, Sennhauser FH, Mallol J. International comparison of asthma prevalence in children: Australia, Switzerland, Chile. Pediatr Pulmonol 1993; 16: 219-226.
25. Pearce N, Weiland S, Keil U, et al. Self-reported prevalence of asthma symptoms in children in Australia, England, Germany and New Zealand: an international comparison using the ISAAC protocol. Eur Respir $J$ 1993; 6: 1455-1461.

26. Brunekreef B, Dockery DW, Speizer FE, et al. Home dampness and respiratory morbidity in children. Am Rev Respir Dis 1989; 140: 1363-1367.

27. Platt SD, Martin CJ, Hunt SM, Lewis CW. Damp housing, mold growth, and symptomatic health state. $\mathrm{Br}$ Med J 1989; 298: 1673-1678.

28. Dales RE, Zwanenburg H, Burnett R, Franklin CA. Respiratory health effects of home dampness and molds among Canadian children. Am J Epidemiol 1991; 134: 196-203.

29. Spengler J, Neas L, Nakai S, et al. Respiratory symptoms and housing characteristics. Indoor Air 1994; 4: $72-82$.

30. Verhoeff AP, van Strien RT, van Wijnen JH, Brunekreef B. Damp housing and childhood respiratory symptoms: the role of sensitization to dust mites and molds. Am J Epidemiol 1995; 141: 103-110.

31. Brunekreef B, Groot B, Hoek G. Pets, allergy and respiratory symptoms in children. Int J Epidemiol 1992; 21: $338-342$.

32. Haahtela T. The prevalence of allergic conditions and immediate skin test reactions among Finnish adolescents. Clin Allergy 1979; 9: 53-60.

33. Haahtela T, Björkstén F, Heiskala M, Suoniemi I. Skinprick test reactivity to common allergens in Finnish adolescents. Allergy 1980; 35: 425-431.

34. Pöysä L. Atopy in children with and without a family history of atopy. II. Skin reactivity. Acta Paediatr Scand 1989; 78: 902-906.

35. Nielsen NH, Svendsen UG, Madsen F, Dirksen A. Allergen skin test reactivity in an unselected Danish population. The Glostrup Allergy Study, Denmark. Allergy 1994; 49: 86-91.

36. Haahtela T, Jokela H. Asthma and allergy in Finnish conscripts. Allergy 1979; 34: 413-420.

37. Clough JB, Williams JD, Holgate ST. Effect of atopy on the natural history of symptoms, peak expiratory flow, and bronchial responsiveness in 7 and 8 year old children with cough and wheeze: a 12 month longitudinal study. Am Rev Respir Dis 1991; 143: 755-760.

38. Lebecque P, Kiakulanda P, Coates AL. Spirometry in the asthmatic child: is FEF25-75 a more sensitive test than FEV1/FVC? Pediatr Pulmonol 1993; 16: 19-22.

39. Croner S, Kjellman N-IM. Natural history of bronchial asthma in childhood: a prospective study from birth up to 12-14 years of age. Allergy 1992; 47: 150-157.

40. Sears MR. Epidemiology. In: Barnes PJ, Rodger IW, Thomson NC, eds. Asthma, Basic Mechanisms and Clinical Management. 2nd edn. London, Academic Press Ltd, 1992; pp. 1-19.

41. Johnson D, Osborn LM. Cough variant asthma: a review of the clinical literature. J Asthma 1991; 28: 85-90.

42. Clough JB, Holgate ST. Episodes of respiratory morbidity in children with cough and wheeze. Am J Respir Crit Care Med 1994; 150: 48-53. 